\title{
Resenha sobre o livro Manual de Sobrevivência para Divulgar Ciência e Saúde
}

\author{
Review of the book Manual de Sobrevivência para Divulgar \\ Ciência e Saúde
}

\author{
Reseña del libro Manual de Sobrevivência para Divulgar \\ Ciência e Saúde
}

\begin{abstract}
MANUAL DE SOBREVIVÊNCIA PARA DIVULGAR CIÊNCIA E SAÚDE. Chagas C, Massarani L. Rio de Janeiro: Editora Fiocruz; 2020. 152 p. ISBN 978-65-5708-027-6.
\end{abstract}

doi: 10.1590/0102-311X00153721

O livro tem uma amplitude que o torna bastante atraente para o público em geral. Não apenas os profissionais da divulgação científica vão gostar da leitura, todos os interessados no tema encontrarão em suas páginas uma envolvente análise de fatos e um conjunto de argumentos e explanações que instigam os leitores a melhor conhecer e aprofundar o assunto. Afinal, como tratar questões da atualidade da ciência e da saúde sem fazer tábula rasa do processo de construção de conhecimentos no mundo contemporâneo? Não ser hermético no sentido da compreensão do discurso que percorre o fazer científico, com seus códigos e regras características, mas também não ser reducionista ao tratar a comunicação pública da ciência e tecnologia como uma simples ação ou efeito de transmitir ideias.

Em tempos tão difíceis para a humanidade, de incontáveis anacronismos políticos ligados à ausência de conhecimentos e de informações de qualidade, o que está em jogo é muito mais do que o atraso e o negacionismo científico. A crítica das autoras em relação ao alcance das informações num mundo conectado, permanentemente, por redes de Internet - por definição, sociais -, é com certeza um dos aspectos do problema da comunicação interpares que não pode ser, na atualidade, menosprezado. Como elas afirmam em várias passagens do livro que tratam das dificuldades e dos desafios para que conhecimentos e informações de qualidade sejam disponibilizados, há de toda a evidência uma crise instaurada nas sociedades atuais. E está ligada a uma preocupante e crescente dose de insegurança em relação aos conteúdos e à disseminação de informações. E não se trata apenas da desqualificação dos atores sociais que propagam informações falsas e anticientíficas.

Como nos bons e velhos manuais, suas orientações práticas e dicas de como fazer projetos de divulgação científica são extremamente úteis. Visto como um livro para não iniciados, há, obviamente, diferentes possibilidades de leituras. Entre elas, destacam-se conselhos e recomendações capazes de facilitar a vida de quem quer fazer divulgação científica com responsabilidade e ética, mas ainda não tem experiência. Os incautos devem ter prudência, não apenas discernimento. Os leitores atentos terão ainda sugestões para construírem seus projetos. Além de um extenso repertório de valores e princípios para guiá-los nesse campo transversal de conhecimentos, as autoras preocuparam-se em refletir sobre os caminhos que vêm sendo trilhados pelos especialistas da área, os quais têm dedicado ao diálogo entre ciência e sociedade um importante e renovado interesse acadêmico.

Preparado no contexto dos meses anteriores à disseminação do vírus nomeado SARS-CoV-2, 
o texto toma forma definitiva de publicação, justamente no momento que foi anunciada a existência de uma pandemia pela Organização Mundial da Saúde (OMS). Este fato está bem descrito logo no início do livro e, de maneira pendular, acompanha ao longo da leitura algumas interpretações relativas às fraudes e controvérsias científicas. Como fica evidente nas argumentações das autoras, não há como desviar-se desse evento que marcará para sempre o ano de 2020. Afinal, muito tem nos inquietando os referidos movimentos negacionistas, principalmente ao associar politização da ciência e posturas anticientíficas ao conjunto de debates e evidências produzidas pelos pesquisadores que buscam soluções para enfrentar a COVID-19. Sem entrar em detalhes, o texto narra episódios ocorridos nos primeiros meses da pandemia e justifica de maneira cabal a importância que tem o diálogo da ciência com a sociedade.

Para além do contexto, a proposta do Manual é nitidamente pensar como a divulgação científica pode e deve ajudar cientistas e não cientistas a estabilizarem enunciados cruciais sobre conhecimentos produzidos nos laboratórios, nas universidades, nos hospitais, enfim, em espaços de ciência \& tecnologia (C\&T), nas mais diversas áreas da pesquisa e da saúde. A própria comunicação como estratégia de aproximação dos enunciados científicos é acionada como chave para sensibilizar a sociedade e os tomadores de decisão acerca do desenvolvimento do país e dos recursos financeiros.

Para além de uma discussão sobre linguagens acessíveis aos diferentes públicos, o livro em questão é resultado também de um trabalho de pesquisa de fôlego que procura mostrar como podem ser produzidos e apresentados conteúdos de ciência e saúde à sociedade. Sendo este pano de fundo, um mote para que as autoras pleiteiem algo que é de per si polêmico: podem os leigos formar opinião sobre temas científicos? Como e por que fazê-lo? Aparentemente, se os esforços realizados forem adequados e convergentes, porque não? Contudo o mais interessante é como elas escolheram desenvolver ideias sobre "por onde começar" a preparar projetos de divulgação científica. A metade do livro é dedicada a esse objetivo. Elas discorrem longamente sobre concepções e estratégias de divulgação científica que podem ser utilizadas para dar respostas aos desafios do tempo presente. Além de proposições, o livro traz muitas dicas e aborda de modo objetivo o que pode ser feito para ampliar e fortalecer o diálogo com a sociedade.

Em relação aos argumentos e enunciados da divulgação científica como estratégia para o avanço da ciência, existem questões que não caberiam neste manual, mas não podem ser esquecidas. Longe do olhar do público, a ciência vem se transformando em algo muito diferente daquilo que havia sido pautado por alguns filósofos, como Paul Feyerabend (1924-1994), que escreveram sobre a ciência como uma imposição da cultura ocidental 1 . Isso não quer dizer que a verdade científica seja pura abstração intelectual. Ao contrário, como sabemos, tornou-se evidente que a ciência produz fatos que não podem ser negados e contraditos. Como diriam Latour \& Woolgar 2, é preciso confiar nas instituições que produzem verdades. Como sabemos, em ciência devemos sempre nos ater à discutibilidade dos argumentos. O que não podemos aceitar é a produção da ignorância e desinformação em escala global.

Há mais de quatro décadas que o campo interdisciplinar dos Estudos de Ciência e Tecnologia ou Science and Technology Studies vem demonstrando que não se pode entender C\&T como simples resultados do esforço intelectual de um ou mais homens e mulheres geniais, e sim como construção humana que se dá num lugar e num tempo histórico determinados por conflitos, questionamentos e interesses de quem vive aquela realidade 3,4 . Praticada por profissionais de várias áreas de conhecimentos, as ciências são vistas como uma entre as diversas formas humanas de conhecer, como as artes, as filosofias, as religiões e as culturas populares.

Por outro lado, já não há espaço em nossa sociedade para a crença absoluta na ciência. As controvérsias científicas adentraram a arena pública e, com isso, não existem mais certezas definitivas. Não sejamos como os críticos vorazes que colocam em dúvida todas as conquistas realizadas pelos cientistas. Não vamos nos iludir ou enganar, elas são reais, tangíveis e têm mudado ao longo da história a nossa realidade cotidiana. Tampouco ingênuos, pois as recorrentes fake news não são uma espécie de produção de inver- 
dades. As notícias fraudulentas servem a determinado fim e, via de regra, tentam igualmente escamotear o quanto é complicado desenvolver argumentos que convençam a todos sobre o valor e a utilidade da ciência.

Para os divulgadores científicos bem-preparados, não há como fugir ao debate, trata-se de ultrapassar obstáculos que impedem com frequência a realização de discussões sobre o significado da ciência em ação. Apesar das autoras afirmarem que "não se controlam" conteúdos depois de produzidos, seria mais ponderado assumir que sempre existem instâncias interessadas em embaralhar e confundir o público.

A ciência tem desempenhado um papel único, de grande relevância no que concerne à vida em toda a sua extensão e complexidade cotidiana. E, no campo da divulgação científica, não tergiversamos. A ciência é a forma de compreensão do mundo que nos dá as melhores condições para "conectar necessidades individuais a projetos coletivos" 5. Ela não tem mais como encastelar-se no topo das torres de marfim, como se dizia no século XX. Ao que tudo indica, existem novos e acachapantes fatos que demonstram que a produção e a circulação da ciência têm fortes imbricações políticas entre Estado e sociedade, abrangendo todo o conjunto de atores sociais que estão implicados no processo de comunicação pública. Este enredo é, especialmente, importante porque as iniciativas existentes até o momento destacam-se como fundamentais para o processo de construção de pontes entre pesquisa e mundo social. Cientistas, divulgadores, cidadãos: mãos à obra!

Cristina Araripe Ferreira 1

1 Casa de Oswaldo Cruz, Fundação Oswaldo Cruz,

Rio de Janeiro, Brasil.

cristina.araripe@fiocruz.br

\section{Informação adicional}

ORCID: Cristina Araripe Ferreira (0000-00021300-1008).

1. Feyerabend P. Contra o método. São Paulo: Editora Unesp; 2011.

2. Latour B, Woolgar S. Laboratory life: the construction of scientific facts. London: Sage; 1986.

3. Felt U, Fouché R, Miller CA, Smith-Doer L. The handbook of science and technology studies. 4th Ed. Cambridge: The MIT Press; 2016.

4. Gingras Y. Sociologie des sciences. Paris: PUF; 2017.

5. Costa A, Roque T. Ciência e política em tempos de negacionismo. Revista Ciência Hoje 2020; 06 jul. https://cienciahoje.org.br/artigo/cienciae-politica-em-tempos-de-negacionismo/. 